\title{
Stratigraphic Nomenclature of
}

- Volcanic Rocks in the

\section{Jemez Mountains, New Mexico}

By R. A. BAILEY, R. L. SMITH, and C. S. ROSS

\section{CONTRIBUTIONS TO STRATIGRAPHY}

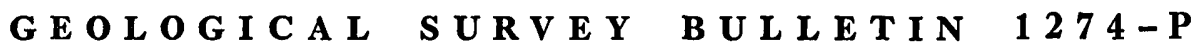

New stratigraphic names and revisions in nomenclature of upper Tertiary and Quaternary volcanic rocks in the Jemez Mountains

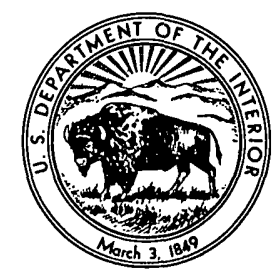




\section{UNITED STATES DEPARTMENT OF THE INTERIOR}

WALTER J. HICKEL, Secretary

\section{GEOLOGICAL SURVEY}

William T. Pecora, Director

U.S. GOVERNMENT PRINTING OFFICE

WASHINGTON : 1969 


\section{CONTENTS}

\begin{tabular}{|c|c|}
\hline \multicolumn{2}{|l|}{ 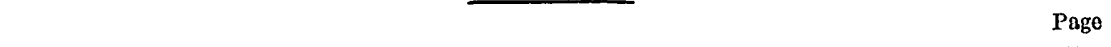 } \\
\hline Abstract. & $\mathrm{P} 1$ \\
\hline Introduction & 1 \\
\hline General relations & 2 \\
\hline Keres Group & 2 \\
\hline Canovas Canyon Rhyolite & 5 \\
\hline Paliza Canyon Formation & 6 \\
\hline Bearhead Rhyolite & \\
\hline Cochiti Formation. & \\
\hline Polvadera Group. & 10 \\
\hline Lobato Basalt. & 10 \\
\hline Tschicoma Formation & 11 \\
\hline El Rechuelos Rhyolite..... & 11 \\
\hline Puye Formation........ & 12 \\
\hline Tewa Group.. & 12 \\
\hline Bandelier Tuff & 13 \\
\hline Tsankawi Pumice Bed & 14 \\
\hline Valles Rhyolite & 15 \\
\hline Deer Canyon Member & 15 \\
\hline Redondo Creek Member & 15 \\
\hline Valle Grande Member & 16 \\
\hline Battleship Rock Member. & 17 \\
\hline El Cajete Member & 17 \\
\hline Banco Bonito Member & 18 \\
\hline eferences.- & 19 \\
\hline
\end{tabular}

\section{ILLUSTRATIONS}

Figure 1. Index map of the Jemez Mountains, New Mex., showing quadrangle boundaries and distribution of Keres, Polvadera, and

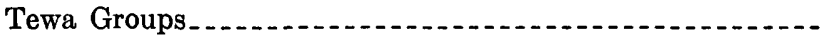
2. Nomenclature of the Keres, Polvadera, and Tewa Groups....- 



\title{
CONTRIBUTIONS TO STRATIGRAPHY
}

\section{STRATIGRAPHIC NOMENGLATURE OF VOLGANIC ROGKS IN THE JEMEZ MOUNTAINS, NEW MEXICO}

\author{
By R. A. BaILex, R. L. Smitu, and C. S. Ross
}

\section{ABSTRACT}

Upper Tertiary and Quaternary volcanic rocks of the Jemez Mountains are subdivided into three groups-the Keres Group, in the south, the Polvadera Group, mainly in the north, and the Tewa Group, in the central and flanking parts of the mountains.

The Keres Group is divisible informally into two subgroups-an older subgroup, consisting of the basalt of Chamisa Mesa and the Canovas Canyon Rhyolite, and a younger subgroup, consisting of the Paliza Canyon Formation and the Bearhead Rhyolite. The older subgroup is a basalt-rhyolite association; the younger subgroup is a more differentiated basalt-andesite-dacite-rhyolite association.

The Polvadera Group includes the Lobato Basalt; the andesites, dacites, and quartz latites of the Tschicoma Formation; and El Rechuelos Rhyolite. These formations constitute a still younger basalt-andesite-dacite-rhyolite association in the Jemez Mountains.

The Tewa Group includes the Bandelier Tuff, Cerro Rubio Quartz Latite, Cerro Toledo Rhyolite, and the Valles Rhyolite and represents the climax of rhyolitic volcanism in the Jemez Mountains.

Subdivision of the Bandelier Tuff is revised so that it consists of only two members-the Otowi Member, which includes the Guaje Pumice Bed, and the Tshirege Member, which includes the Tsankawi Pumice Bed. The Valles Rhyolite is subdivided into six new members. Ages of many of the formations are refined by radiometric dating.

\section{INTRODUCTION}

The main purpose of this paper is to define and briefly describe new geologic formations recognized and mapped in the Jemez Mountains volcanic field in north-central New Mexico. The nomenclature of some previously described units is revised. The formations are shown on the geologic map of the Jemez Mountains (Smith and others, 1969). 


\section{GENERAL RELATIONS}

The volcanic rocks of the Jemez Mountains (Ross and others, 1961; Smith and others, 1961) are stratigraphically and petrologically divisible into three groups, herein named the Keres Group, the Polvadera Group, and the Tewa Group. The Keres Group occurs mainly in the southern Jemez Mountains and is overlapped and unconformably overlain by the Polvadera Group, which occurs mainly in the central and northern Jemez Mountains. The Tewa Group occurs in the central and flanking parts of the mountains and unconformably overlies both the Keres and Polvadera Groups (fig. 1).

In general, the rocks of the Keres and Polvadera Groups constitute two successive petrochemical cycles, ranging from basalt through intermediate rocks to rhyolite. The rocks of the Tewa Group constitute a climactic and terminal rhyolitic stage of volcanism.

Figure 2 shows the nomenclature of the Keres, Polvadera, and Tewa Groups listed in general stratigraphic succession.

The Keres and Polvadera Groups for the most part overlie buff arkosic sediments of late Tertiary age. These sediments constitute most of the alluvial fill of the Rio Grande graben and were initially called the "Santa Fe marl" (Hayden, 1869) and later the Santa Fe Formation (Bryan, 1938; Smith, 1938; Denny, 1940; Galusha, 1966). Spiegel and Baldwin (1963) proposed that the Santa Fe be raised to group status and separated it into the Tesuque and Ancha Formations in the vicinity of Santa Fe. Because of uncertainties in the correlation of the Tesuque and Ancha Formations with other Santa Fe beds in and adjacent to the Jemez Mountains, however, the term Santa Fe Formation, as used by Denny, Smith, and Galusha, is used in this paper. In the northern Jemez Mountains, the Santa Fe Formation includes the sediments above the Abiquiu Tuff of Smith (1938) and below the Lobato Basalt (new name, this paper). East of the Jemez Mountains, the Santa $\mathrm{Fe}$ Formation includes the sediments exposed below the Puye Formation and below the basalts of Cerros del Rio, although it is recognized that the uppermost of these beds east of the Rio Grande belongs to the Ancha Formation. Southwest of the Jemez Mountains, the Santa Fe Formation includes the sediments above the Zia Sand Formation of Galusha (1966) and below the basalt of Chamisa Mesa and the Cochiti Formation (new name, this paper).

\section{KERES GROUP}

The Keres (pronounced kear'-ees) Group is here proposed for a sequence of basaltic, andesitic, dacitic, and rhyolitic volcanic rocks forming the southern Jemez Mountains. The name is derived from an old name for the southern Jemez Mountains-the Keresan Range 
VOLCANIC ROCKS, JEMEZ MOUNTAINS, NEW MEXICO

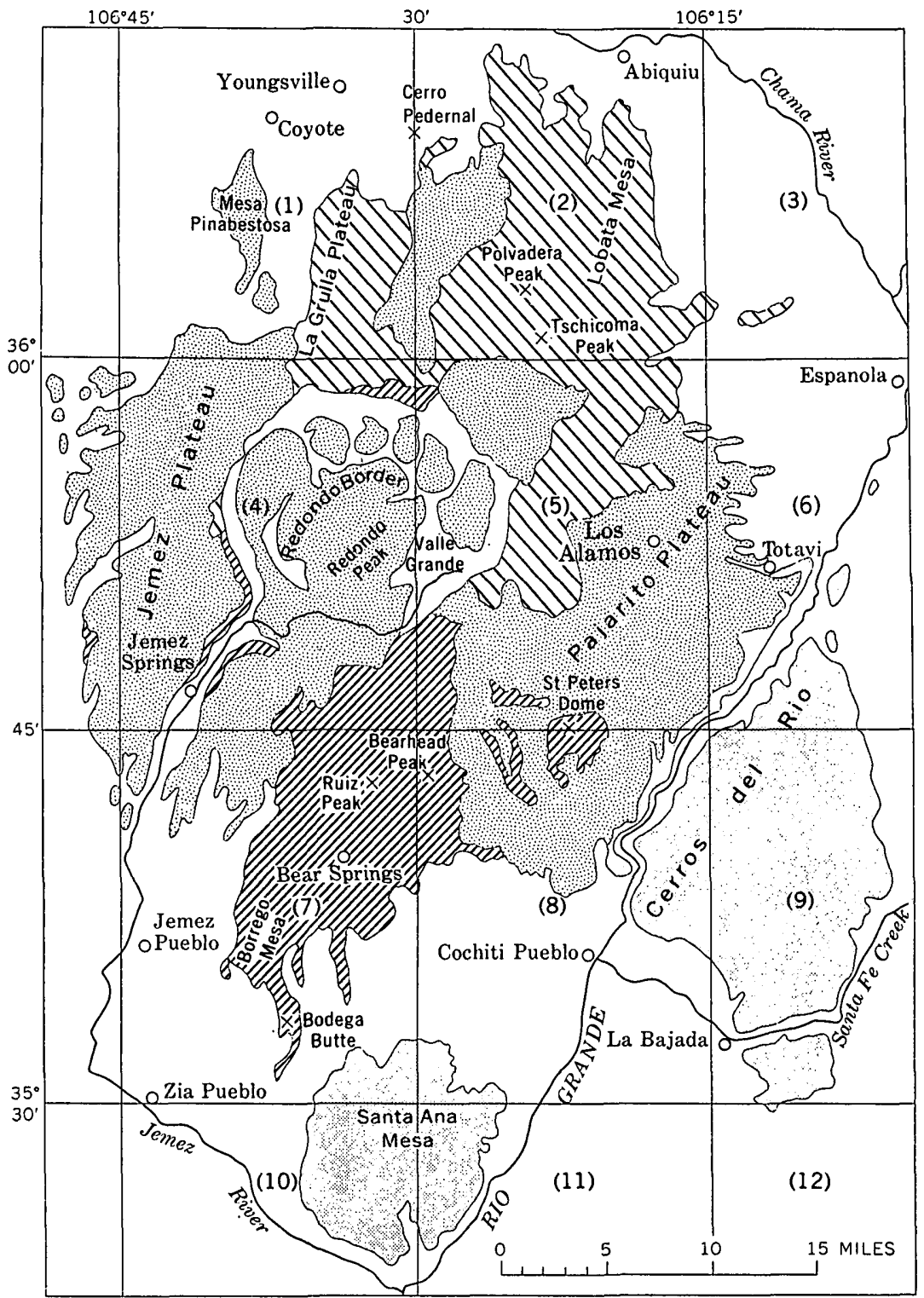

\section{EXPLANATION}
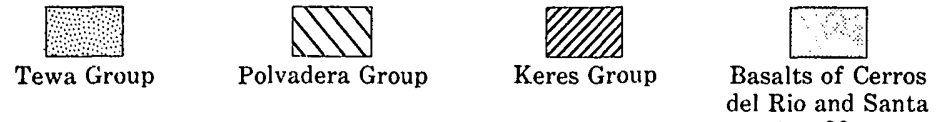

Ana Mesa

Figure 1.-Index map of the Jemez Mountains, N. Mex., showing distribution of the Keres, Polvadera, and Tewa Groups and boundaries of the following quadrangles: (1) Youngsville, (2) Abiquiu, (3) San Juan Pueblo, (4) Jemez Springs, (5) Frijoles, (6) Espanola, (7) Jemez, (8) Santo Domingo Pueblo, (9) Agua Fria, (10) Bernalillo, (11) San Felipe Pueblo, and (12) Madrid. 


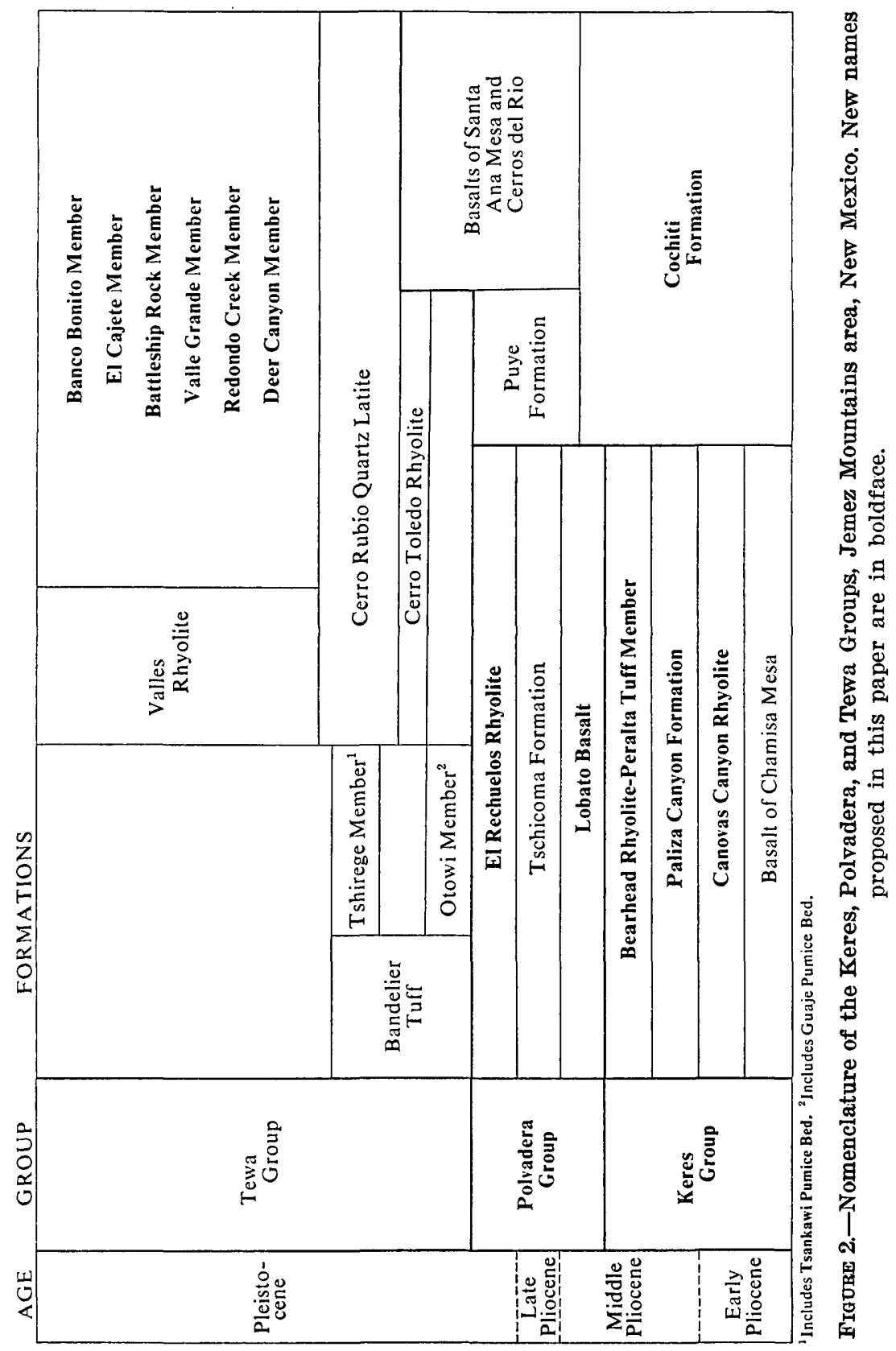


(Harrington, 1916, p. 409), which was named for the Indians of the Keresan linguistic group who inhabited the surrounding area.

The Keres Group includes, from oldest to youngest, the basalt of Chamisa Mesa, the Canovas Canyon Rhyolite, the Paliza Canyon Formation, and the Bearhead Rhyolite (new names, this paper).

The Keres Group may be divided informally into two subgroupsan older subgroup, consisting of the basalt of Chamisa Mesa and the Canovas Canyon Rhyolite, and a younger subgroup, consisting of the Paliza Canyon Formation and the Bearhead Rhyolite. The older subgroup is a predominantly basalt-rhyolite association; the younger subgroup is a more differentiated basalt-andesite-dacite-rhyolite association.

The Keres Group has an aggregate maximum thickness of more than 6,000 feet, but because of the lenticular nature of most of its component formations, the maximum thickness in any given place does not exceed 3,000 feet.

The Keres Group ranges in age from early through middle Pliocene. The group conformably overlies upper Miocene(?) and lower Pliocene arkosic sands of the Santa $\mathrm{Fe}$ Formation and interfingers with volcanic gravels of the Cochiti Formation. The Keres Group is unconformably overlain by middle and upper Pliocene and Pleistocene volcanic rocks of the Polvadera and Tewa Groups.

\section{CaNOVAS CANYON RHYOLITE}

The name Canovas Canyon Rhyolite is proposed for a sequence of rhyolite flows, tuffs, domes, and associated shallow intrusions exposed in the eastern half of the Jemez quadrangle. The formation is named for exposures in Canovas Canyon, but the most typical exposures are to the east, in the Bear Springs area, particularly on Bear Springs Peak, which is one of several source vents for the formation.

The formation has a maximum thickness of 900 feet in the Bear Springs area, where it consists of alternating bedded tuffs, massive pumice breccias, and lava flows, which are locally intruded by small rhyolite bodies. The formation extends 7 to 8 miles south and southwest of Bear Springs and underlies most of Borrego Mesa, where it thins to less than 100 feet and consists mainly of bedded tuffs, although one isolated extrusive center occurs at Borrego Dome.

In the Bear Springs area the Canovas Canyon Rhyolite directly overlies arkosic sands of the Santa Fe Formation, which crop out only locally -0.7 mile southeast of Bear Springs Peak in a minor branch of Bear Springs Canyon and 0.6 mile northwest of Bear Springs Peak near the head of Canovas Canyon.

$329-579-69-2$ 
On Borrego Mesa, tuffs of the Canovas Canyon Rhyolite conformably overlie the basalt of Chamisa Mesa, which in turn conformably overlies arkosic sands of the Santa Fe Formation. The basal contact of the formation is intermittently exposed along the western edge of the mesa as far south as Bodega Butte.

In the Borrego Mesa area, tuffs of the Canovas Canyon Rhyolite interfinger with gravels of the lower part of the Cochiti Formation and are conformably overlain by basalts of the Paliza Canyon Formation. In the Bear Springs area, where the relief near the rhyolite vents is great, the Canovas Canyon is overlapped, locally with steep contacts, by Paliza Canyon basalts and andesites.

The Canovas Canyon Rhyolite is probably early Pliocene in age. The formation postdates arkosic sands of the Santa Fe Formation that Galusha (1966, p. 11) considers to be equivalent to the Valentine Formation of Nebraska (upper Miocene and lower Pliocene as indicated by Wood and others, 1941). The formation predates dacites of the Paliza Canyon Formation that have been radiometrically dated by G. B. Dalrymple (written commun., 1967) as 8.5 to 9.1 m.y. (million years) old.

\section{PAIIZA CANYON FORMATION}

The name Paliza (pronounced pal-ee'-sah) Canyon Formation is proposed for a complex of basaltic, andesitic, and dacitic flows, tuffs, and breccias that crop out extensively in the Jemez Springs, Jemez, Frijoles, and Santo Domingo Pueblo quadrangles. The formation is named for exposures in Paliza Canyon, in the southeastern part of the Jemez Springs quadrangle, although the best exposures occur in upper Cochiti Canyon and on the east side of St. Peter's Dome in the Frijoles quadrangle, where the rocks have been carved into steep rugged slopes of nearly continuous outcrop.

The rocks represent the effusions of numerous coalesced composite volcanoes, and because such deposits are inherently lenticular, a type area, rather than a type section, is designated. In any given section, however, there is a general upward succession from basaltic through andesitic to dacitic rocks, although locally dacitic rocks may occur low in the succession.

The formation is thickest along a north-south axis extending from the north wall of the Valles caldera through Paliza and Peralta Canyons to Ruiz Peak, where exposures generally exceed 1,500 feet. The base of the formation is not exposed along this axis, but projection from the exposed base west of the axis indicates that the maximum thickness of the formation is about 3,000 feet. 
The Paliza Canyon Formation overlies rocks ranging in age from Permian to late Tertiary. On the western fringes of the Jemez Mountains on the east side of Rio Guadalupe, La Ventana quadrangle, and at the head of Canon de San Diego, Jemez Springs quadrangle, Paliza Canyon basalts and andesites unconformably overlie red beds of the Abo Formation (Permian). In lower Paliza Canyon, Jemez quadrangle, they unconformably overlie red shales of the Chinle Formation (Triassic). On the west wall of the Valles caldera and in upper San Juan Canyon, Jemez Springs quadrangle, Paliza Canyon basalts are in contact with light-grayish-buff sands and tuffaceous lake(?) sediments that are thought, on the basis of lithology, to be correlative with the Abiquiu Tuff of Miocene(?) age. At the east foot of St. Peter's Dome, Frijoles and Santo Domingo quadrangles, the formation rests conformably(?) on buff arkosic sands of the Santa Fe Formation of probable late Miocene(?) or early Pliocene age. In the Bear Springs area, Jemez quadrangle, Paliza Canyon basalts and andesites lap unconformably against the high-standing hills of Canovas Canyon Rhyolite, but on Borrego Mesa, to the southwest, similar basalts conformably overlie tuffs of the Canovas Canyon Rhyolite and sandy gravels of the Cochiti Formation.

The Paliza Canyon Formation is intruded and locally overlain by units of the Bearhead Rhyolite. The contact between the two formations is variable, being locally conformable and elsewhere disconformable or unconformable. The overall impression gained, however, is that the Bearhead Rhyolite erupted on an irregular erosional surface cut on the Paliza Canyon rocks.

In the north and northwest wall of the Valles caldera, Jemez Springs and Frijoles quadrangles, andesite flows of the Paliza Canyon Formation are overlain with apparent conformity by the thick dacite and quartz-latite flows of the Tschicoma Formation (Polvadera Group). However, the alteration of the andesitic rocks in comparison with the very fresh appearance of the dacitic rocks suggests a disconformity or unconformity between the formations. The Paliza Canyon Formation is also locally overlain unconformably by the Bandelier Tuff (Tewa Group).

The Paliza Canyon Formation is early to middle Pliocene in age. Three dacitic rocks from the formation have been dated by the potassium-argon method as being 8.5, 8.8, and 9.1 m.y. old (G. B. Dalrymple, written commun., 1967). On Borrego Mesa, basalts in the lower part of the formation postdate late Miocene(?) and early Pliocene sediments of the Santa $\mathrm{Fe}$ Formation (Galusha, 1966) and are separated from them by about 200 feet of the Cochiti Formation, the Canovas Canyon Rhyolite, and the basalt of Chamisa Mesa. The formation predates 
basaltic and dacitic rocks of the Polvadera Group, which have radiometric ages of 7.4 m.y. and younger (G. B. Dalrymple, written commun., 1967).

\section{BEARHEAD RHYOLITE}

The name Bearhead Rhyolite is proposed for a thick accumulation of rhyolite tuffs, flows, domes, and associated shallow intrusions that are exposed in the northern parts of the Santo Domingo Pueblo and Jemez quadrangles and the southern parts of the Frijoles and Jemez Springs quadrangles. The formation is named for exposures on Bearhead Peak, one of the larger source vents of the formation.

Tuffaceous facies of the Bearhead Rhyolite are here formally designated the Peralta Tuff Member, a name first used by Kirk Bryan and J. E. Upson (Stearns, 1953, pp. 499-500). The member is named for typical exposures in Peralta Canyon near its junction with Colle Canyon. The Peralta Tuff Member consists predominantly of bedded air-fall tuffs but includes probable hot-avalanche deposits, as well as reworked tuffs that are interbedded with and grade laterally into volcanic gravels of the Cochiti Formation.

The Bearhead Rhyolite rests for the most part on an irregular erosion surface cut mainly on andesitic and dacitic rocks of the Paliza Canyon Formation. Contact relations are well exposed in Sanchez, Cochiti, and Bland Canyons, in the Santo Domingo Pueblo quadrangle, and near Cerrito Yelo, in the Jemez quadrangle. At the mouth of Bland Canyon the Peralta Tuff Member rests conformably on tuff breccias of the Paliza Canyon Formation, and at Tent Rocks in Peralta Canyon the tuffs interfinger with the upper part of the Cochiti Formation.

The Bearhead Rhyolite is unconformably overlain southwest of Tent Rocks by pediment gravels that are probably correlative with those of the Ortiz pediment (Bryan, 1938, p. 215; Stearns, 1953).

The Bearhead Rhyolite is middle Pliocene in age. The formation postdates the Paliza Canyon Formation, which contains rocks that have been radiometrically dated as 8.5 to 9.1 m.y. old (G. B. Dalrymple, written commun., 1967), and it predates pediment gravels that appear to be correlative with those of the Ortiz pediment-the Tuerto Gravel of Stearns (1953) and the Ancha Formation (Spiegel and Baldwin, 1963, p. 49 and fig. 20), which are considered to be of late Pliocene or early Pleistocene age.

\section{COCHITI FORMATION}

The Cochiti (pronounced co'-chi-tee) Formation is a thick sequence of volcanic gravel and sand, consisting of basalt, andesite, dacite, and 
rhyolite detritus derived from penecontemporaneous erosion of units of the Keres Group. The formation is named for exposures in the badlands west and southwest of Cochiti Pueblo, in the western half of the Santo Domingo Pueblo quadrangle, and the eastern half of the Jemez quadrangle. The formation is repeated by faulting, and its full thickness is nowhere exposed.

The formation is exposed from Borrego Mesa and Bodega Butte eastward to the Rio Grande and south of the Jemez Mountains to the southern end of Santa Ana Mesa.

The base of the formation is exposed only along its western edge and is placed at the top of the basalt of Chamisa Mesa, above which the enclosing arkosic sediments contain volcanic detritus from the Jemez Mountains. The lower part of the Cochiti, along the southern edge of Borrego Mesa and in the vicinity of Bodega Butte, is interbedded with tuffs of the Canovas Canyon Rhyolite, but to the north it overlies Canovas Canyon tuffs and is separated by them from the basalt of Chamisa Mesa.

In Canovas, Hondo, and Guacamalla Canyons, coarse gravels of the Cochiti Formation are interbedded with basalts and andesites of the Paliza Canyon Formation, and at Tent Rocks in Peralta Canyon, gravels of the upper part of the formation are interbedded with the Peralta Tuff Member of the Bearhead Rhyolite.

The formation becomes finer grained southward from the Jemez Mountains, and under Santa Ana Mesa it grades laterally into coarse sands which become redder by inclusion of more and more granitic debris at the expense of volcanic debris. These coarse sands were mapped by Spiegel (1961) as the "red member of the Santa Fe Group" and were believed by him to be older than the Cochiti Formation, which he called the "western facies of the Santa Fe Group"; intertonguing and the gradation between Jemez-derived volcanic debris and granitic debris, however, especially on the north and west side of Santa Ana Mesa, indicate that the two facies are, in large part, time equivalent.

The Cochiti Formation is unconformably overlain in the north by pediment gravels that are probably equivalent to those of the Ortiz pediment (Bryan, 1938; Stearns, 1953). It is overlain in the south by the basalts of Santa Ana Mesa.

The Cochiti Formation ranges in age from early through middle Pliocene. The formation interfingers with the Paliza Canyon Formation, which contains dacites that have radiometric ages of 8.5 to 9.1 m.y. It postdates arkosic sands of the Santa $\mathrm{Fe}$ Formation (upper Miocene and lower Pliocene), and it predates pediment gravels considered equivalent to the Tuerto Gravel (upper Pliocene or lower Pleistocene) of Stearns (1953). 


\section{POLVADERA GROUP}

The name Polvadera (pronounced pol-vah-dare'-ah) Group is here proposed for the sequence of basaltic, andesitic, dacitic, and ryholitic rocks that form part of the central and most of northern Jemez Mountains. The name is derived from Polvadera Peak, the second highest peak in the northern Jemez Mountains and one of the major volcanic centers of the group.

The Polvadera Group includes, from oldest to youngest, the Lobato Fasalt (new name, this paper), the andesites, dacites, rhyodacites, and quartz latites of the Tschicoma Formation (Griggs, 1964, p. 42), and El Rechuelos Rhyolite (new name, this paper). The group is a basaltandesite-dacite-rhyolite association younger than that of the Keres Group, which it overlaps to the south.

The Polvadera Group has an aggregate thickness of about 5,000 feet, but because most of the formations are lenticular and only in part coextensive, the maximum thickness in any one place does not exceed 3,500 feet.

The Polvadera Group unconformably overlies the Abiquiu Tuff of Smith (1938) and arkosic sands of the Santa $\mathrm{Fe}$ Formation in the nerth and unconformably overlies the Keres Group in the central Jemez Mountains. The group is unconformably overlain locally by rocks of the Tewa Group.

Rocks of the Polvadera Group range in age from middle Pliocene to early Pleistocene. A basalt from Polvadera Mesa (Lobato Basalt) has been dated radiometrically as $7.4 \mathrm{~m}$.y., and one of the youngest domes of El Rechuelos Rhyolite has been dated as 2.0 m.y. (G. B. Dalrymple, written commun., 1967).

\section{LOBATO BASALT}

The name Lobato Basalt is proposed for the basaltic lavas that form the high-level mesas fringing the northern and northeastern sides of the Jemez Mountains. The formation includes the basalts of Clara Peak, Lobato Mesa, Polvadera Mesa, and Escoba Mesa in the Abiquiu quadrangle and of Cerro Pedernal and La Grulla Plateau in the Youngsville quadrangle. The formation is named for Lobato Mesa in the eastern half of the Abiquiu quadrangle, where the formation is thickest and most extensive. H. T. U. Smith (1938) briefly referred to the basalts on Lobato Mesa as the "Lobato basaltic lavas" but did not describe them or formally name them.

Lobato Mesa is designated the type area for the formation. Typical sections are well exposed on the eastern escarpment of the mesa. The formation has a maximum thickness of 600 feet on Lobato Mesa and consists of a succession of many flows ranging from 20 to 50 feet in 
thickness. The flows are predominantly olivine-augite basalts, but hypersthene-, pigeonite-, and titaniferous augite-bearing varieties also occur.

The Lobato basalts rest on an erosional surface locally veneered by boulders and cobbles of Precambrian crystalline and metamorphic rocks and underlain by Abiquiu Tuff and arkosic sands of the Santa Fe Formation. The Lobato basalts are overlain for the most part by dacites and quartz latites of the Tschicoma Formation, but in Rio del Oso an early dacite flow of the Tschicoma Formation is interbedded with the basalts.

The Lobato Basalt is middle Pliocene in age. A radiometric age of 7.4 m.y. has been obtained on one flow from Polvadera Mesa (G. B. Dalrymple, written commun., 1967). The formation postdates the Abiquiu Tuff of Miocene(?) age and arkosic sediments of the Santa Fe Formation of probable late Miocene and early Pliocene age. The formation for the most part predates the Tschicoma Formation, which on the basis of radiometric dating is middle to late Pliocene in age.

\section{TSCHICOMA FORMATION}

The Tschicoma Formation has been defined and described by Griggs (1964, p. 42). Recent radiometric dates of 6.7 to 3.7 m.y. (G. B. Dalrymple, written commun., 1967) on rocks from the formation indicate an age of middle to late Pliocene.

\section{EL RECHUELOS RHYOLITE}

The name El Rechuelos (pronounced el rech-way'-los) Rhyolite is proposed for the rhyolite that forms five small rhyolite domes and a small pumice cone in the northern Jemez Mountains. The formation is named for El Rechuelos, a small steep draw which drains the western side of Polvadera Peak in the Abiquiu quadrangle and which passes just south of the two largest domes of the formation.

The formation includes the small pumice cone of El Lagunito de Palo Quemador, 2.5 miles north of Polvadera Peak, two pumiceous rhyolite domes about 2 miles northwest of Polvadera Peak, a small obsidian dome 1.2 miles southwest of Polvadera Peak, and two lithic rhyolite masses at the head of Canoncito Seco, about 5 miles southwest of Polvadera Peak.

The several masses rest on dacitic rocks of the Tschicoma Formation, and a few are locally overlain by the Bandelier Tuff. A radiometric age of $2.0 \mathrm{~m}$.y., which has been obtained on the largest of the domes, indicates an early Pleistocene age, but the two masses at the head of Canoncito Seco may be older, judging from their degree of denudation and alteration. 


\section{PUYE FORMATION}

The Puye (pronounced poo'-yay) Gravel was named and first mapped in the Abiquiu quadrangle by H. T. U. Smith (1938), but no definition or description of the formation appeared in print until Griggs (1964) published the results of his mapping in the Los Alamos area. Griggs separated the Puye into two members-the Totavi Lentil, a basal river gravel, consisting mainly of Precambrian quartzites and crystalline rock types; and a fanglomerate member, consisting mainly of volcanic rocks derived from the Jemez Mountains. Griggs used the name Puye Conglomerate, rather than Puye Gravel, because the deposits are sufficiently consolidated to stand in vertical cliffs. The name Puye Formation is proposed here, however, because most of the constituent materials of the formation are of ultimate pyroclastic origin, and many of the component beds, especially those close to the source areas in the Jemez Mountains, are pumiceous tuffs and lithic lapilli tuffs that show only slight alluvial reworking. Mudflow (lahar) deposits also constitute a large part of the formation; their greater coherence largely accounts for the clifflike outcrops.

The Puye Formation is essentially a broad alluvial and pyroclastic fan flanking the east side of the northern Jemez Mountains. It bears in a general way the same relation to the Polvadera Group rocks that the older Cochiti Formation bears to the Keres Group rocks in the southern Jemez Mountains. The formation is interbedded in Santa Clara Canyon with thick massive dacite and quartz latite flows of the Tschicoma Formation, with which it is in large part penecontemporaneous. It is also interbedded with the basalts of Chino Mesa (Cerros del Rio) (Griggs, 1964, p. 36).

The Puye Formation unconformably overlies arkosic sands of the Santa Fe Formation and is conformably overlain by the Otowi Member of the Bandelier Tuff.

The Puye Formation is middle to late Pliocene in age. Stratigraphic relations indicate that it is penecontemporaneous with the Tschicoma Formation, several flows of which have been radiometrically dated 6.7 to 3.7 m.y. old (G. B. Dalrymple, written commun., 1967). The Puye predates the Otowi Member of the Bandelier Tuff, which has been dated as 1.4 m.y. old.

\section{TEWA GROUP}

Nomenclature of the Tewa (pronounced Tay'-wah) Group was mutually agreed upon by C. S. Ross, R. L. Smith, and R. L. Griggs in 1952 and was published by Griggs (1964). The group includes the Bandelier Tuff, Cerro Toledo Rhyolite, Cerro Rubio Quartz Latite, and the Valles Rhyolite, a voluminous sequence of rhyolitic tuffs and lavas that represent the climactic and terminal stage of volcanism in the Jemez Mountains. 
No changes are proposed in the nomenclature of the group, but revision and further subdivision of some of its constituent formations are proposed below.

\section{BANDELIER TUFF}

The term "Bandelier Rhyolite Tuff" was first used by H. T. U. Smith (1938, fig. 4, p. 937). It was shortened to "Bandelier Tuff" by Griggs $(1964$, p. 46), and the unit was subdivided by him into three members. From bottom to top these were: (1) The Guaje Member, a bedded pumice-fall deposit, (2) the Otowi Member, a massive pumiceous tuff breccia of ash-flow origin, and (3) the Tshirege Member, a succession of cliff-forming welded ash flows. Although this 3-fold subdivision was suitable for mapping the Los Alamos area, subsequent recognition of the significance of a pumice-fall bed at the base of the Tshirege Member and additional knowledge of the overall character of the Bandelier, plus genetic considerations, have shown that the formation may be more naturally subdivided into two stratigraphic and genetically equivalent units, each consisting of a basal pumice fall overlain by a petrologically related succession of ash flows. In a previous paper (Smith and Bailey, 1966), these two subdivisions were referred to informally as the "upper" and "lower" members of the Bandelier. The Bandelier is here formally divided into two members. The lower member is designated the Otowi Member, which is extended to include (1) the basal pumice fall (Guaje Member of Griggs) and (2) the overlying ash-flow units (Otowi Member of Griggs). Griggs' Guaje Member is renamed the Guaje Pumice Bed. The upper member of the Bandelier is designated the Tshirege Member and includes (1) a basal pumice fall, here named the Tsankawi Pumice Bed, and (2) the overlying ash-flow units (Tshirege Member of Griggs). Formal names are not given to the ash-flow units of either the Otowi or Tshirege Members. The table below compares Griggs' subdivisions with those of this report and with the informal designations of Smith and Bailey (1966).

\begin{tabular}{|c|c|c|c|}
\hline Griggs (1964) & Smith and Bailey & \multicolumn{2}{|c|}{ This report } \\
\hline Tshirege Member & $\begin{array}{l}\text { "upper, } \\
\text { member" }\end{array}$ & $\begin{array}{l}\text { Tshirege } \\
\text { Member }\end{array}$ & $\begin{array}{c}\text { Ash-flow units } \\
\text { Tsankawi Pumice } \\
\text { Bed }\end{array}$ \\
\hline Otowi Member & $\begin{array}{l}\text { "lower } \\
\text { member" }\end{array}$ & $\begin{array}{l}\text { Otowi } \\
\text { Member }\end{array}$ & Ash-flow units \\
\hline
\end{tabular}


The Tsankawi Pumice Bed, the only new name proposed, and the only unit of the Bandelier not yet described in the literature, is defined below.

TSANKAWI PUMICE BED

The Tsankawi (pronounced tsahn-kah'-wee) Pumice Bed is named for exposures in the general vicinity of Tsankawi Ruin on the Pajarito Plateau, Espanola quadrangle. Typical and readily accessible exposures may be seen at several places along the south side of Tsankawi Ruin mesa, in secs. 20 and 21, T. 19 N., R. 7 E.; in the middle of sec. 24, T. 19 N., R. 6 E., on the Los Alamos truck route in Sandia Canyon; and in roadcuts along New Mexico Route 4 where it crosses Potrillo and Ancho Canyons.

In the type area the Tsankawi ranges in thickness from 2 to $3 \frac{1}{2}$ feet and typically consists of three distinct air-fall units that are recognizable over its entire extent. The lower, main unit, 16-36 inches thick, consists of coarse, crudely bedded ash and pumice lapilli reaching a maximum of 2 inches in diameter. Above this is a thin, 1- to 2-inchthick bed of crystal-rich ash. This in turn is overlain by 4-10 inches of medium coarse pumice and ash, similar to, but better sorted and more distinctly bedded than the lower, main unit.

Over most of the Pajarito Plateau, the Tsankawi Pumice Bed rests on nonwelded pumiceous tuff breccia (ash flows) of the Otowi Member of the Bandelier or on bedded tuffs and associated gravels of the Cerro Toledo Rhyolite.

At most exposures the Tsankawi Pumice Bed is directly overlain by nonsorted pumiceous tuff breccia of the Tshirege ash flows, but locally as much as 2 feet of reworked, crossbedded ash is between the pumice bed and the ash flows.

Initially, the Tsankawi Pumice Bed blanketed the entire Jemez Mountains area, for outcrops of it occur beneath the Tshirege ash flow units on all sides of the mountains. The bed is thickest to the west and northwest, on the Jemez Plateau and Mesa Pinabetosa, where it attains a maximum thickness of about 12 feet.

The typical pumice of the Tsankawi Bed is rhyolitic. It is light gray to white and has a fibrous structure and silky luster on fresh surfaces. It contains sparse phenocrysts of quartz and sanidine and rare black specks of oxides and ferromagnesian minerals. This typical pumice is not particularly useful in distinguishing the Tsankawi Pumice Bed from other pumice falls in the area, but the presence in the Tsankawi of 1-10 percent of relatively dense gray pumice containing abundant hornblende needles is diagnostic. This gray, hornblende-bearing pumice is unique to the Tshirege Member of the Bandelier, It occurs both in the basal pumice fall and the ash flow 
units and is a useful criterion for identification of the Tsankawi Bed, as well as the Tshirege ash flows.

The Tsankawi Pumice Bed is Pleistocene in age and has been dated radiometrically as $1.1 \mathrm{~m}$.y. old (Doell and others, 1968).

\section{VALLES RHYOLITE}

The name Valles (pronounced vah'-yes) Rhyolite was proposed (Griggs, 1964, p. 58) for the rhyolites within the Valles caldera. The formation includes all the rhyolites that erupted within the caldera after its collapse.

The formation is here subdivided into the following six members listed and described in order of decreasing age: Deer Canyon Member, Redondo Creek Member, Valle Grande Member, Battleship Rock Member, El Cajete Member, and Banco Bonito Member.

\section{DEER CANYON MEMBER}

The name Deer Canyon Member is given to petrographically distinctive rhyolites in the central part of the Valles caldera, mainly in the Jemez Springs quadrangle. The member is named for the domeflow and associated tuffs exposed in Deer Canyon on the southwest side of Redondo Border, but it includes two isolated outcrops of similar rhyolite exposed in upper Jaramillo and San Luis Creeks and a sequence of rhyolite tuffs and breccias exposed on the northeast extension of Redondo Peak. Deer Canyon is designated the type area. Here the rhyolite has a maximum thickness of about 100 feet, typically contains abundant large bipyramidal phenocrysts of quartz and blocky phenocrysts of sanidine, and lacks visible ferromagnesian minerals.

The Deer Canyon Member in most localities conformably overlies a thin veneer of red, sedimentary caldera fill, which in turn overlies the uppermost ash-flow units of the Tshirege Member of the Bandelier Tuff. In upper San Luis Creek, the Deer Canyon is overlain by a flow of the Redondo Creek Member of the Valles Rhyolite, and on the northeast extension of Redondo it is conformably overlain by coarse, sedimentary caldera fill.

The Deer Canyon Member postdates the Tshirege Member of the Bandelier Tuff and predates the Redondo Creek Member of the Valles Rhyolite.

\section{REDONDO CREEK MEMBER}

The name Redondo Creek Member is given to petrographically distinctive rhyolites in the central and western parts of the Valles caldera. The member is named for the rhyolite dome and associated dikes and flows exposed at the head of Redondo Creek, Jemez Springs quadrangle, but a thicker section occurs in the steep slopes on the 
west side of Sulphur Creek between Sulphur Springs and La Cueva. Here the member has a maximum thickness of about 500 feet and consists mainly of perlitic flow breccias.

The Redondo Creek Member is distinguishable from other members of the Valles Rhyolite by its distinctive sanidine-rimmed plagioclase phenocrysts and by its complete lack of quartz phenocrysts. The rock typically contains conspicuous biotite phenocrysts.

The base of the Redondo Creek Member, where exposed, conformably overlies lake beds or sandy sediments of the Valles caldera fill. The member is unconformably overlain, mainly in the western part of the caldera, by units of the Valle Grande Member of the Valles Rhyolite.

\section{VALLE GRANDE MEMBER}

The name Valle Grande (pronounced vah'-yeh grahn'-deh) Member is given to the rhyolites that form the morphologically young domes, flows, and associated pyroclastic rocks in the moat of the Valles caldera. The member includes the rhyolite of the domical masses of Cerro del Medio, Cerros de los Posos, Cerros del Abrigo, Cerro Santa Rosa, Cerro San Luis, Cerro Seco, San Antonio Mountain, South Mountain, and Cerro La Jara. The member is named for Valle Grande, the large valley in the southeastern part of Valles caldera, from which many of the domes can be seen. A type section is not designated because of the isolated nature of the units forming the member and because of petrographic differences between them. The domes in the eastern part of the caldera (Cerro del Medio and Cerros de los Posos) are nearly free of phenocrysts, whereas those in the western and southern parts (San Antonio Mountain and South Mountain) contain conspicuous quartz, sanidine, plagioclase, biotite, hornblende, and pyroxene phenocrysts. Progressive mineralogical variation between these extremes and the annular distribution of the domes within the Valles caldera moat, however, indicate that they are petrologically related and are parts of a single geologic member.

Basal contacts of the Valle Grande Member are seldom exposed. Locally, basal pyroclastic units of the member conformably overlie or interfinger with young lake sediments in the caldera moat. In the western half of the caldera, the dome-flow of San Antonio Mountain overlies the Redondo Creek Member. The South Mountain dome-flow is the only unit of the Valle Grande Member that is directly overlain by younger members of the Valles Rhyolite. It is disconformably overlain in Jemez Creek by the Battleship Rock, El Cajete, and Banco Bonito Members.

Although tree covered, most of the domes of the Valle Grande Member are so young that they have not been modified appreciably by 
erosion, and some retain their original carapace of glassy pumiceous blocks. Twelve of the domes have been dated radiometrically and have ages ranging from about 0.4 to 1.0 m.y. (Doell and others, 1968).

\section{BATTLESHIP ROCK MEMBER}

The name Battleship Rock Member is given to a sequence of local rhyolitic ash-flow deposits cropping out at the head of Canon de San Diego, in the Jemez Springs quadrangle. The member is named for Battleship Rock, which is also designated the type section, in sec. 5, T. 18 N., R. 3 E.

Near Battleship Rock the member is 400 feet thick and consists of a succession of ash flows that are in part welded. Location of the eruptive vent for the Battleship Rock Member is not known with certainty, but the distribution and petrographic similarity of the Battleship Rock Member with the El Cajete Member and the Banco Bonito Member suggest that the vent was in the vicinity of El Cajete.

Over most of the extent of the member, the base is not exposed, but at Battleship Rock the unit rests unconformably on red beds of the Abo Formation (Permian) and on fossiliferous limestones of the Magdalena Group (Pennsylvanian) and seems to have once filled a narrow gorge cut in these formations. The upper surface of the Battleship Rock Member locally has been deeply incised by streams and is in most places disconformably overlain by the porphyritic obsidian flow of the Banco Bonito Member of the Valles Rhyolite.

Contact relations about 1 mile northeast of Battleship Rock indicate that the member postdates the South Mountain dome-flow of the Valle Grande Member, which has been dated radiometrically as 0.49 m.y. old (Doell and others, 1968). The Battleship Rock Member predates both the El Cajete Member, which contains fragments of Battleship Rock welded tuff, and the Banco Bonito Member, which overlies the El Cajete.

\section{EL CAJETE MEMBER}

The El Cajete (pronounced el kah-heh'-teh) Member of the Valles Rhyolite is a mantle-bedded air-fall deposit of rhyolite pumice lapilli and blocks. It is named for its source vent, El Cajete crater, which is about 2 miles south of Redondo, in the Jemez Springs quadrangle. Because of its incoherence and the vegetational cover, natural outcrops of the member are rare. Excellent exposures are provided, however, by many roadcuts along New Mexico State Route 4 between Triple H Ranch and the crossing of the East Fork of Jemez Creek.

The El Cajete pumice forms a nearly continuous blanket over the countryside for 5 miles south of El Cajete crater, and isolated patches of it occur throughout the southern Jemez Mountains. Thin remnant 
patches also are known to be nearly 30 miles from El Cajete, for example, in the canyon of the Santa Fe River, near La Bajada, in the Aqua Fria quadrangle. In the rim of El Cajete crater and in El Cajete Canyon, the member has a maximum thickness of about 250 feet.

The youngest rock directly overlain by the El Cajete Member is the South Mountain dome-flow of the Valle Grande Member of the Valles Rhyolite. Inclusions of Battleship Rock welded tuff in the El Cajete Member, however, indicate that the El Cajete postdates the Battleship Rock Member also. The El Cajete Member is overlain only by the Banco Bonito Member. A charcoal sample (U.S.G.S. No. W1553), collected from a thin ash-flow unit overlying El Cajete pumice in a roadcut at the crossing of Route 4 with the East Fork of Jemez Creek, was dated as greater than 42,000 years B.P. (before present) (Meyer Rubin, written commun., 1965).

\section{BANCO BONITO MEMBER}

The name Banco Bonito (pronounced bahn'-ko bon-ee'-toe) Member of the Valles Rhyolite is proposed for the porphyritic obsidian flow that fills the southwestern moat of the Valles caldera. It is named for Banco Bonito, the steep slope forming the south margin of the flow in the central part of the Jemez Spring quadrangle.

The Banco Bonito obsidian flow issued from a vent immediately west of El Cajete crater, flowed west 3 miles, and then bifurcated into two tongues, one of which flowed north and the other south, each an additional 2 miles. Although sparsely forested with ponderosa pine, the flow is virtually unmodified by erosion, and concentric pressure ridges on the flow surface are well preserved.

The basal contact of the Banco Bonito flow is well exposed only along its western margin, in the vertical cliff forming the east wall of upper San Diego Canyon. Here the flow fills steep narrow valleys cut into underlying welded ash flows of the Battleship Rock Member. On its southern margin, the flow unconformably overlies red beds of the Abo Formation and disconformably overlies the South Mountain flow of the Valle Grande Member and the El Cajete Member of the Valles Rhyolite.

The Banco Bonito obsidian flow is the youngest eruptive unit in the Jemez Mountains and is probably not more than 100,000 years old. The flow postdates the youngest unit of the Valle Grande Member which has been dated as 0.43 m.y. old (Doell and others, 1968). It also postdates a thin ash-flow unit that has been dated as greater than 42,000 years B.P. by carbon-14. Conformity of the basal contact of the obsidian flow with the thin ash-flow unit and the well-preserved surface features on the obsidian flow suggest that its age is nearer 42,000 years than 0.43 m.y. 


\section{REFERENCES}

Bryan, Kirk, 1938, Geology and ground-water conditions of the Rio Grande depression in Colorado and New Mexico, in [U.S.] Natl. Resources Planning Board, Rio Grande Joint Investigation, Regional Planning, Part 6, Upper Rio Grande: Washington, U.S. Govt. Printing Office, v. 1, pt. 2, p. 197-225.

Denny, C. S., 1940, Santa Fe formation in the Española Valley, New Mexico: Geol. Soc. America Bull., v. 51, no. 5, p. 677-693.

Doell, R. R., Dalrymple, G. B., Smith, R. L., and Bailey, R. A., 1968, Paleomagnetism, potassium-argon ages, and geology of the rhyolites and associated rocks of the Valles Caldera, New Mexico: Geol. Soc. America Mem. 116, p. 211-248.

Galusha, Ted, 1966, The Zia Sand Formation, new early to medial Miocene beds in New Mexico: Am. Mus. Nat. History, Am. Mus. Novitates, no. 2271, 12 p.

Griggs, R. L., 1964, Geology and ground-water resources of the Los Alamos area, New Mexico : U.S. Geol. Survey Water-Supply Paper 1753, $107 \mathrm{p}$.

Harrington, J. P., 1916, The ethnogeography of the Tewa Indians: U.S. Bur. Am. Ethnology. Ann. Rept. 29, 1907-1908, p. 29-636.

Hayden, F. V., 1869, Preliminary field report [third annual] of the United States geological survey of Colorado and New Mexico: Washington, D.C., 155 p.

Ross, C. S., Smith, R. L., and Bailey, R. A., 1961, Outline of the geology of the Jemez Mountains, New Mexico, in New Mexico Geol. Soc., Guidebook of the Albuquerque country, 12th Field Conf., October 6-8, 1961: Socorro, New Mexico Bur. Mines and Mineral Resources, p. 139-143.

Smith, H. T. U., 1938, Tertiary geology of the Abiquiu quadrangle, New Mexico: Jour. Geology, v. 46, no. 7, p. 933-965.

Smith, R. L., and Bailey, R. A., 1966, The Bandelier Tuff-A study of ash-flow eruption cycles from zoned magma chambers: Bull. volcanol., ser. 2, v. 29, p. 83-104.

Smith, R. L., Bailey, R. A., and Ross, C. S., 1961, Structural evolution of the Valles Caldera, New Mexico, and its bearing on the emplacement of ring dikes, in Short papers in the geologic and hydrologic sciences: U.S. Geol. Survey Prof. Paper 424-D, p. D145-D149.

- 1969, Geologic map of the Jemez Mountains, New Mexico: U.S. Geol. Survey Misc. Geol. Inv. Map I-571. (In press.)

Spiegel, Zane, 1961, Late Cenozoic sediments of the lower Jemez River region, in New Mexico Geol. Soc., Guidebook of the Albuquerque country, 12th Field Conf., October 6-8, 1961: Socorro, New Mexico Bur. Mines and Mineral Resources, p. 132-138.

Spiegel, Zane, and Baldwin, B. W., 1963, Geology and water resources of the Santa Fe area, New Mexico: U.S. Geol. Survey Water-Supply Paper 1525, $258 \mathrm{p}$.

Stearns, C. E., 1953, Tertiary geology of the Galisteo-Tonque area, New Mexico: Geol. Soc. America Bull., v. 64, no. 4, p. 459-508.

Wood, H. E., Chaney, R. W., Clark, John, Colbert, E. H., Jepsen, G. L., Reeside, J. B., Jr., Stock, Chester, 1941, Nomenclature and correlation of the North American continental Tertiary: Geol. Soc. America Bull. v. 52, no. 1, p. 1-48. 